\title{
Analysis On Written Mathematical Communication Skills At System Of Linear Equations In Two Variables (SLETV) Material Viewed From Student Learning Styles
}

\author{
Isnin Cahyo Pratiwi, Siti Inganah, Octavina Rizky Utami Putri \\ Mathematics Education Study Program, Faculty of Education and Teacher Training \\ University of Muhammadiyah Malang \\ isninpratiwii@gmail.com
}

\begin{abstract}
This research was to describe students' mathematical communication skills based on their learning styles. This research was a descriptive research with qualitative approach. Data was obtained in three steps, namely written test on SLETV material, questionnaire on learning styles, and interviews. Research subject was eighth grade students. The procedure in this research began with the pre-field stage. At this stage, the research was designed, starting from observation and interviews with the teacher, as well as discussion with the supervisor. The second was the field stage, which was the stage for conducting research. The final stage was writing the report, which was the stage where researchers have conducted the research, processed and analyzed data that has been obtained from the research. Data collection techniques in this research were distributing questionnaire, giving test questions about SLETV, and conducting interviews to find out the students' mathematical communication skills more specifically. The instruments in this study were questionnaire on learning styles, test questions about SLETV, and interview guide sheets. Data analysis techniques in this research aimed to achieve data reduction by sorting out important answers from student results in the form of questionnaire, test, and interviews. Data presentation was in the form of narrative texts. Interviews were aligned with the test questions about SLETV. Finally, conclusions were formulated by describing each student's written mathematical skill based on the 4 student learning styles. Based on the results, students with interpersonal learning style had the ability to learn better through friendship, students with self-expressive learning style had the ability to learn by paying more attention to the final results and tended to use unusual ways to find the best results, students with understanding learning style had the ability to see facts and remember large amounts of knowledge, ideas, theories, or concepts, while students with mastery learning style were able to write to the point and focus more on results.
\end{abstract}

Keywords: Student Learning Styles, Written Communication Skills, SLETV.

\section{INTRODUCTION}

Teaching and learning process is basically a communication activity. By communicating, students will be able to express ideas and understandings to teachers, friends, and school environment. Based on the Regulation of the Minister of Education and Culture No. 58 of 2014 on the Standard of Mathematics Learning Content, mathematics learning aims to make students be able to communicate reasoning, ideas, and compile mathematical statements and convert them into sentences such as symbols, diagrams, tables, which will be used to analyze mathematical conditions or problems. 
Mathematical communication becomes very important since mathematics contains mathematical symbols in the symbolization process, which will be converted into a mathematical statement in the form of formulas, symbols, tables, and pictures (Gordah \& Nurmangsih, 2015). Mathematical communication is the ability to mathematically express an idea to others, in addition to that mathematical skill is the ability to understand mathematical ideas of others in a critical and evaluative manner in order to deepen their understanding (Lestari \& Yudhanegara, 2014). Written communication is an effective way to analyze students' mathematical communication skills. It is relevant to the opinion of Kosko (2012), who states that writing is the best way for individuals to think and write their knowledge in a detailed and precise way in providing mathematical ideas. According Wardhana and Lutfianto (2018), written communication is the process of conveying thoughts/ideas in writing. Students have different ways of communicating their skills, according to Sukadi (2009) who argues that learning styles are a combination of how one absorbs and processes knowledge/information, learning styles also vary from one student to another. According to Mulyono (2012), every student has a learning style that is different from the other students, not everyone can follow and have the same way of learning. Learning traits related to absorbing, processing, and expressing information are student learning styles. According to Silver et al (2013), in learning, each student has a learning style that is different one to another. There are four student learning styles: (a) mastery, (b) understanding, (c) interpersonal, and (d) self-expressive.

According to Silver et al (2013), mastery learning style is a learning style of students who prefer to learn simple and coherent things according to the procedure. They like questions that are related to what has been done/completed before and will use any means to find the results. They are good at remembering things in detail, speaking and writing to the point, and paying attention to accuracy. Understanding learning style is a learning style of students who are able to identify a problem by analyzing it well and remember a large amount of knowledge and information. They are excellent in learning existing ideas, concepts, and theories. They learn well when they are challenged to think and explain ideas, for example, mathematical problems that require them to explain or prove a matter and take attitude. Interpersonal learning style is a learning style of students who prefer to solve a problem by discussing or speaking with peers. They like learning related to the real world (environment). It is difficult for them to solve a problem individually, but they learn well when the teacher pays attention to students who are smart and persistent in learning mathematics. Self-expressive learning style is a learning style of students who prefer to explore mathematical ideas that they have. It is difficult for them to learn by practicing, exercising, and memorizing, but they enjoy mathematical problems outside the routine and those that are obtained from nature, which make them think "out of the box". They learn well when it is related to imagination and when they are engaged in creative problem solving.

SLETV material is an important material. In this material, students need good communication to be able to solve questions about SLETV. According to Desmita (2009), through questions about everyday problems, students are required to be able to communicate and interpret everyday language into mathematical language and write down the results of calculations that have been carried out according to the problems to obtain a good and correct solution. Based on the results of interviews that have been conducted by researchers with the mathematics teacher, it was found that each student 
has different communication skills. Each teacher gave students time to express their opinions about their answers as they have different communication skills. This is closely related to differences in student learning style that makes their mathematical communication skills vary. This opinion encouraged researchers to carry out research with the title "Analysis on Written Mathematical Communication Skills at SLETV Material Viewed from Student Learning Styles". Thus, this study is to 1) describe students' mathematical communication skills at SLETV material with mastery learning style, (2) describe students' mathematical communication skills at SLETV material with understanding learning style, (3) describe students' mathematical communication skills at SLETV material with interpersonal learning style, and (4) describe students' mathematical communication skills at SLETV material with self-expressive learning style.

Research that are relevant to this research were the research by Zainul (2016), entitled, Analysis of Mathematical Communication Skills in Solving Problems at Linear Equation System with Two Variables on Class VIII-C Students at SMP Nuris Jember; the research by Novi (2017), entitled, Analysis of Students Mathematical Communication Skills at Statistics Material Viewed from Visual, Auditorial, Kinesthetic (VAK) Learning Styles; and the research by Nur (2016), entitled, Analysis of Mathematical Communication Skills of Class XI Students Viewed from Learning Styles in Knisley Learning Model. The results of research by Zainul (2016) state that there are high, medium, and low levels of communication skills among students. These differences imply that there are differences in students that can be seen from their mathematical skills, the higher the students' mathematical skills, the higher their mathematical communication skills. In addition, the results of research by Novi (2017) state that differences in student learning styles make student mathematical communication skills vary. Students with visual learning style have successfully described the answers to the existing questions and they often use symbols. Students with auditorial learning style gave good, long, and detailed answers to the questions. Meanwhile, students with kinesthetic learning style wrote down the given and problem of the questions well then use their own language to explain it. Although the language is difficult to understand, it is still in accordance with the problem of the question. Finally, the results of research by Nur (2016) state that the 34 students in the classroom have various learning styles. There were 16 students with visual learning style, 11 students with auditorial learning style, and 7 students with kinesthetic learning style. Students with visual learning style answered to the written test by writing down the given and problem of the questions and converting problems into a diagram well. Meanwhile, students with auditorial learning style converting problems in the test into a diagram well. They are able to explain mathematical problems by formulating them into good and correct arguments and definitions. Students with kinesthetic learning style were able to listen and reflect in a group work. They also wrote down answers in student worksheets clearly.

\section{RESEARCH METHOD}

This research was a descriptive research. This research used qualitative approach since it aimed to describe students' mathematical communication skills viewed from their mathematical learning styles. The subjects used in this study were 21 seventh grade students of SMP Muhammadiyah 2 Malang. This research was conducted in the even 
semester of the 2018/2019 school year. In order to find out each student's learning style, questionnaire was given to 21 students to be filled out individually. Then, test questions containing 2 questions about SLETV were distributed to be filled out individually. After the students answered to the test questions, researchers began to analyze or process the data by data reduction. Data reduction was sorting out data obtained in the form of questionnaires, tests, and interviews, whether it was primary data or unimportant data. Primary data was chosen in accordance to the research objectives. Primary data was related to the sheets of each test. Steps of data reduction in this research were sorting out the answers into four learning styles: mastery, understanding, interpersonal, and selfexpressive. The results were analyzed by determining the score of the learning style, ranging from 1 to 4 . Determination of learning styles was based on the following criteria:

Table 1: Determination of learning styles

\begin{tabular}{ll}
\hline No & Determination of learning styles \\
\hline 1 & $\begin{array}{l}\text { If the score of mastery is larger than the } 3 \text { other learning styles, the student } \\
\text { is categorized into mastery learning style. }\end{array}$ \\
\hline 2 & $\begin{array}{l}\text { If the score of understanding is larger than the } 3 \text { other learning styles, the } \\
\text { student is categorized into understanding learning style. }\end{array}$ \\
\hline 3 & $\begin{array}{l}\text { If the score of interpersonal is larger than the } 3 \text { other learning styles, the } \\
\text { student is categorized into interpersonal learning style. }\end{array}$ \\
\hline 4 & $\begin{array}{l}\text { If the score of self-expressive is larger than the } 3 \text { other learning styles, the } \\
\text { student is categorized into self-expressive learning style. }\end{array}$ \\
\hline
\end{tabular}

The answers to written test in the form of questions about SLETV was assessed based on sub-indicators in the indicators of students' mathematical communication skills in the appendix. There were 8 students chosen based on their answers to the questions and recommendations from the subject teacher. Indicators of students' written mathematical communication skills used in the research were as follows:

Table 2: Indicators of Student Written Mathematical Communication Skills

\begin{tabular}{|c|c|c|}
\hline No. & Indicators & Rubrics \\
\hline \multirow[t]{4}{*}{1} & \multirow{4}{*}{$\begin{array}{l}\text { Write down mathematical ideas } \\
\text { in accordance to mathematics } \\
\text { questions }\end{array}$} & Do not write down the given and problem \\
\hline & & Only write down the given or the problem \\
\hline & & Write down the given and problem incorrectly \\
\hline & & Write down the given and problem correctly \\
\hline \multirow[t]{4}{*}{2} & \multirow{4}{*}{$\begin{array}{l}\text { Convert questions into } \\
\text { mathematical equations }\end{array}$} & Do not write down any mathematical modeling \\
\hline & & $\begin{array}{l}\text { Most mathematical modeling are incorrect } \\
\text { (incorrect formulation) }\end{array}$ \\
\hline & & $\begin{array}{l}\text { Most mathematical modeling are incorrect } \\
\text { (correct formulation, incorrect answers) }\end{array}$ \\
\hline & & All mathematical modeling are correct \\
\hline \multirow[t]{4}{*}{3} & \multirow{4}{*}{$\begin{array}{l}\text { Use mathematical terms, figures, } \\
\text { and notations }\end{array}$} & Do not use any symbol \\
\hline & & All symbols are incorrect \\
\hline & & Most symbols are incorrect \\
\hline & & All symbols are correct \\
\hline \multirow[t]{2}{*}{4} & \multirow{2}{*}{$\begin{array}{l}\text { Write down the conclusions of } \\
\text { completed questions }\end{array}$} & Do not formulate conclusions \\
\hline & & Conclusions are not in accordance with the \\
\hline
\end{tabular}


problems (incorrect answers and conclusions)

Conclusiona are not in accordance with the

problems (correct answers, incorrect conclusions)

Formulate conclusions correctly (correct answers

and conclusions)

Interviews were conducted by sorting out students who had one of the 4 student learning styles. Each learning style was represented by 2 students. Interviews were conducted face-to-face with students using interview guidelines. After data reduction, the researcher presented the data. Data presentation in this research was in the form of narrative texts. The texts in the form of interviews were concluded and harmonized with the results of students' written test and assessed according to the written test. The next step was formulating conclusions. Conclusions were formulated to describe students' mathematical communication skills viewed from their learning styles, which were known based on the results of written test on students' mathematical communication skills in the form of 2 questions about SLETV and the results of interviews about the answers of the written test.

\section{RESULT AND DISCUSSION}

\section{Analysis of the Student Learning Styles}

Students who answered to the questionnaire of learning styles were classified into the 4 criteria of determining learning styles. The following are the 21 students and their respective learning styles.

Table 1: Learning Style Categories of Class VIII-B Students at SMP Muhammadiyah 2 Malang

\begin{tabular}{llll}
\hline No & Student Name & Learning Style & Electability \\
\hline 1 & AKP & Interpersonal & Selected \\
\hline 2 & A & Self-expression & Selected \\
\hline 3 & ACZ & Material Mastery & Selected \\
\hline 4 & AIS & Understanding & Not Selected \\
\hline 5 & BHS & Material Mastery & Selected \\
\hline 6 & BA & Self-expression & Not Selected \\
\hline 7 & GAV & Understanding & Not Selected \\
\hline 8 & HA & Material Mastery & Not Selected \\
\hline 9 & KV & Self-expression & Not Selected \\
\hline 10 & LA & Interpersonal & Not Selected \\
\hline 11 & LB & Interpersonal & Selected \\
\hline 12 & MRPS & Interpersonal & Selected \\
\hline 13 & MN & Understanding & Not Selected \\
\hline 14 & NRZR & Interpersonal & Not Selected \\
\hline 15 & PFWK & Understanding & Not Selected \\
\hline 16 & PRW & Self-expression & Selected \\
\hline 17 & RS & Material Mastery & Selected \\
\hline 18 & RFD & Understanding & Not Selected \\
\hline 19 & RCK & Interpersonal & Not Selected \\
\hline 20 & SKQ & Interpersonal & Not Selected \\
\hline 21 & WYN & Material Mastery & recommendations from
\end{tabular}

Note: In the electability category, the students were selected by recommendations from subject teacher and based on the students' respective answers. 
The 21 students had different learning styles. There were 5 students with mastery learning style, 5 students with understanding learning style, 7 students with interpersonal learning style, and 4 students with self-expressive learning style. Each learning style was represented by 2 students, so there were 8 students whose mathematical communication skills were analyzed based on the 4 learning styles.

\section{Analysis of Students' Mathematical Communication Skills based on Learning Styles}

Mastery Learning Style Subject
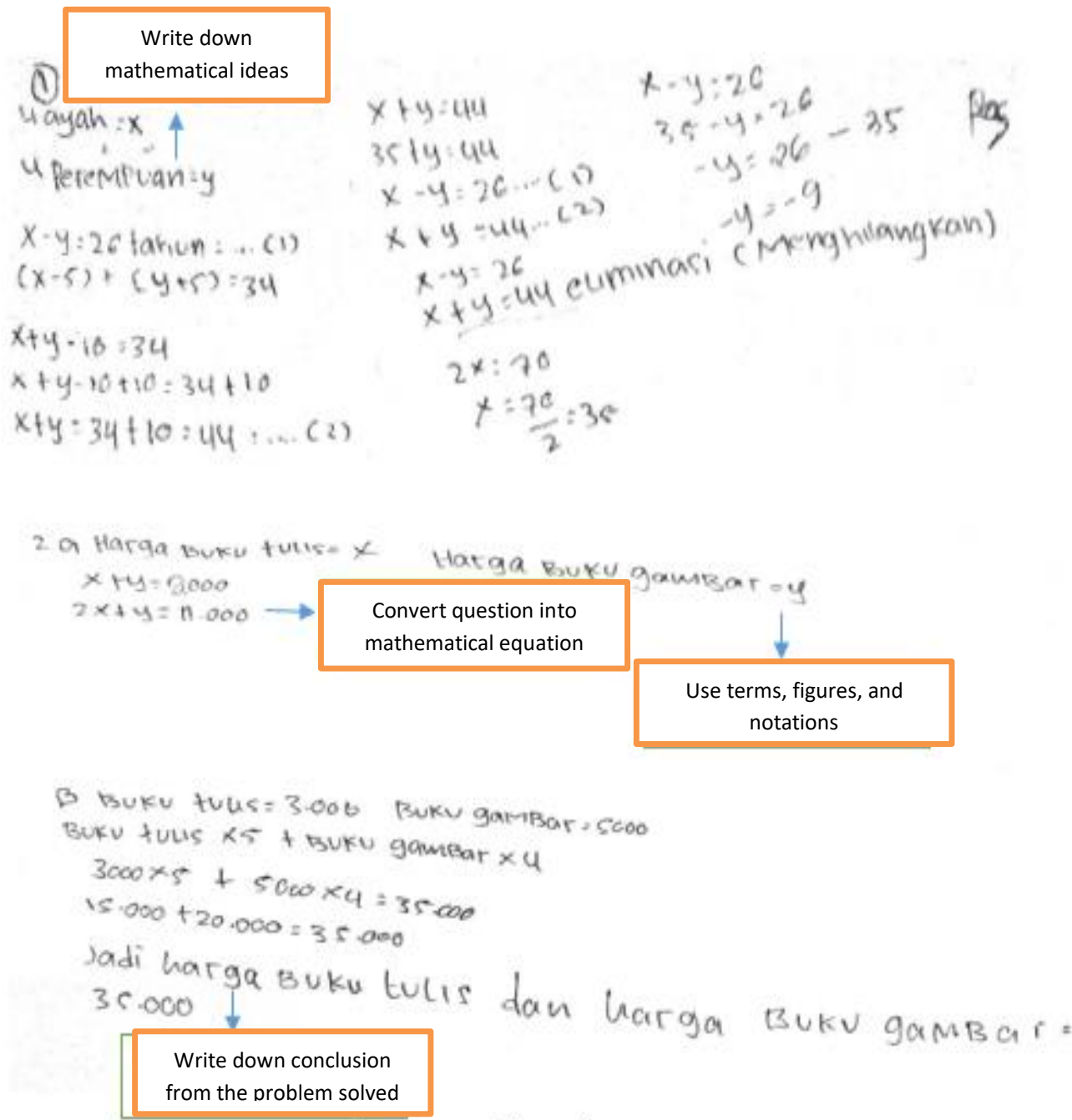

Figure 1: Student RS's Answer

Student RS with mastery learning style answered questions by writing down the given as in umur ayah (father's age) $=x$ and umur anak perempuan (daughter's age) $=y$. However, the student did not write down the problem and some of the mathematical modeling were incorrect even though the student was able to convert the questions into mathematical modeling (correct formulation, incorrect answers). Model made by the student were $x+y=44$ and $x-y=26$. Most of the symbols used were correct, the student wrote down $(+),(-),(=)$ symbols in accordance with mathematical statements. The student did not formulate conclusions except for the question number 2 . The student made correct conclusions: jadi, harga buku tulis dan harga buku gambar adalah Rp 35.000,00 (so, the price of notebook and drawing book is Rp 35.000,00). The 
student with mastery learning style wrote down incorrect the given and problem, for example, $\mathrm{u}$ ayah (father's a) $=x$ supposed to be umur ayah (father's age) $=x$. Students with mastery learning style have the ability to communicate appropriately. Overall, it is in accordance with the indicators of students' mathematical communication skills. Correspondingly, Jean (2015) states that students with mastery learning style are able to write to the point and focus more on results. This is also relevant to Afnaria (2016) who states that students with this learning style can learn well when teaching focuses on modeling, feedback sessions, and training.

Understanding Learning Style Subject

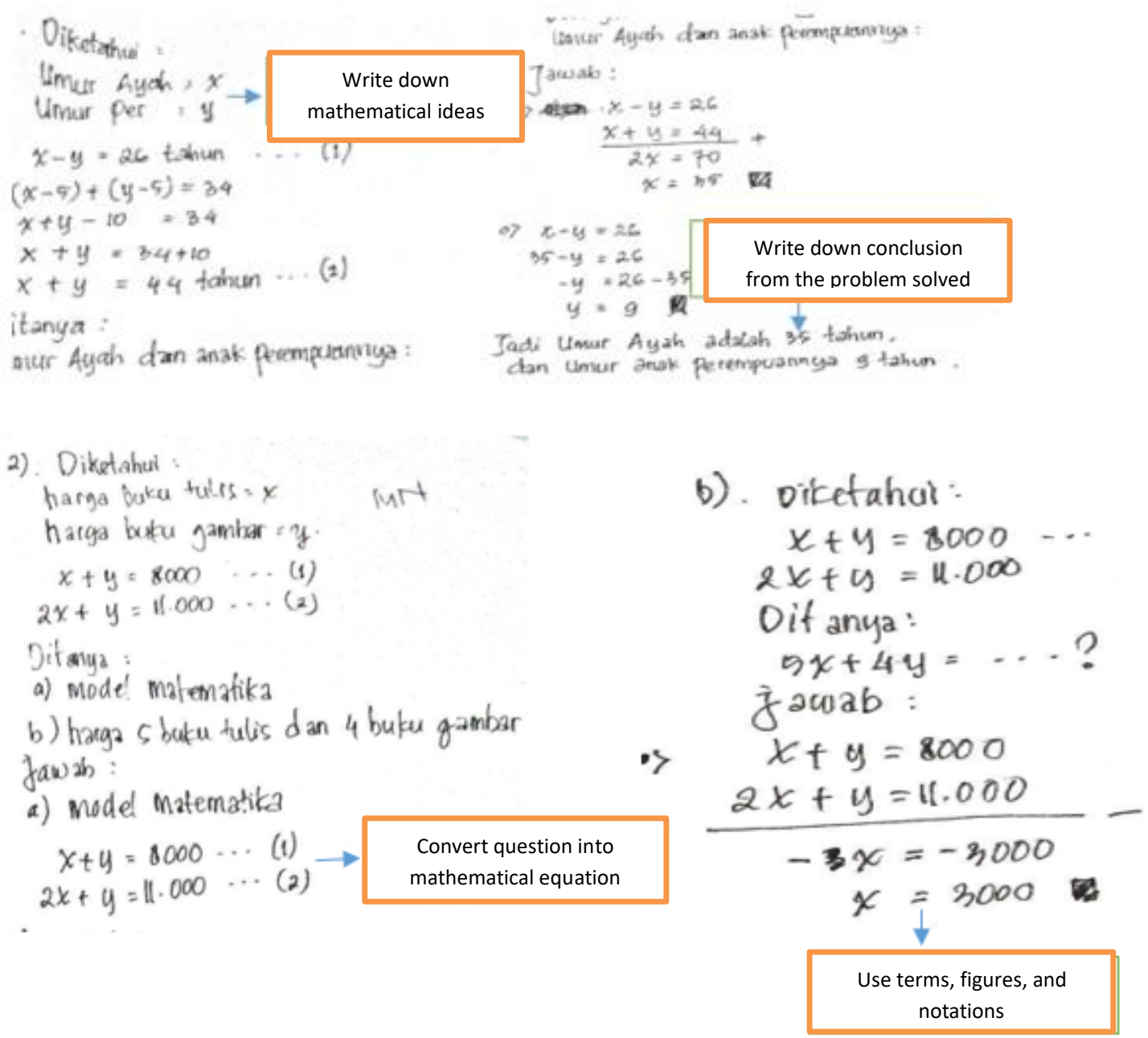

Figure 2: Student MN's Answer

Student MN with understanding learning style answered questions by writing down the given and problem appropriately: harga buku tulis (price of notebook) $=\mathrm{x}$ and harga buku gambar (price of drawing book) $=\mathrm{y}$. All formulation used were correct, the student wrote down $\mathrm{x}+\mathrm{y}=\mathrm{Rp} .8000 .00$ and $2 \mathrm{x}+\mathrm{y}=\mathrm{Rp} .11,000.00$. All symbols used were correct, the student wrote down (+), (-), (=) symbols correctly. The formulation of conclusions was correct and matched with the answer: jadi, harga 5 buku tulis dan 4 buku gambar adalah Rp 35,000.00 (so, the price of 5 notebooks and 4 drawing books is $\mathrm{Rp}$ 35,000.00). Students with understanding learning style do the test precisely 
according to indicators of written mathematical communication skills. Students with understanding learning style learn better individually. As revealed by Ramlan (2014), students experience learning difficulties in discussions, so it is better to learn independently. In addition, they like to explain and prove a problem.

Interpersonal Learning Style Subject

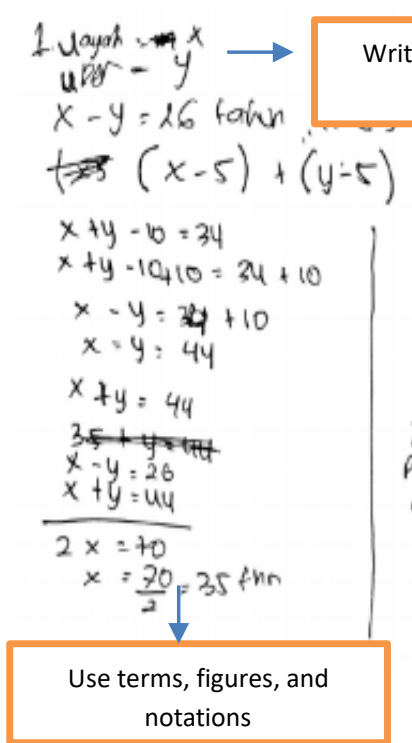

notations

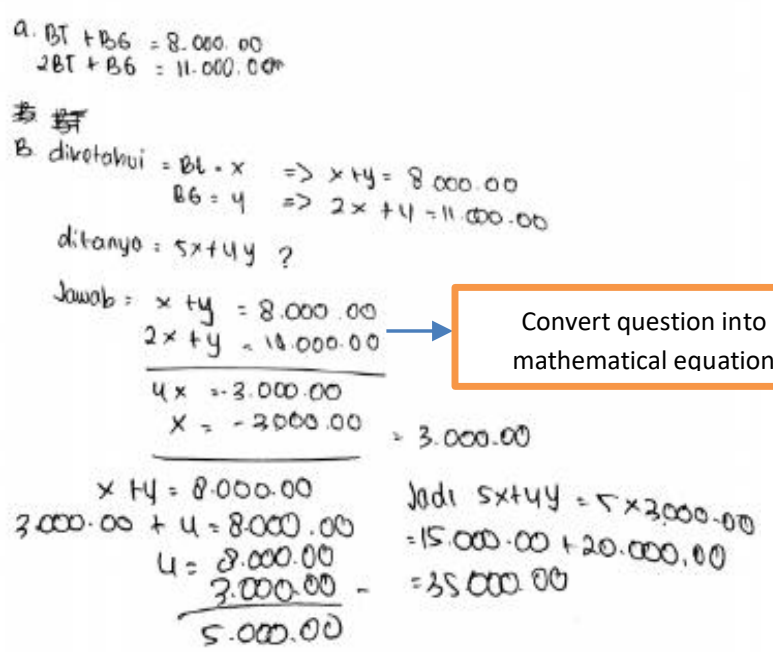

Figure 3: Student AKP's Answer

Student AKP with interpersonal learning style answered the questions by writing down the given but not writing down the problem as in figure 3. The student wrote down $\mathrm{u}$ ayah (father's a) $=\mathrm{x}$ and $\mathrm{u}$ anak perempuan (daughter's age) $=\mathrm{y}$, which were not the correct way to write variables. However, the studient gave an explanation during the interview that $u$ meant usia (age) since the student was accustomed to abbreviate words when writing answers, formulas and modeling as in $\mathrm{x}+\mathrm{y}=44$ and $\mathrm{xy}=26$. All symbols used were correct, the student wrote down (+), (-), (=) symbols correctly. The conclusions were formulated correctly (correct answers and conclusions): jadi, umur anak perempuan adalah 9 tahun dan umur ayah adalah 35 tahun (so, the daughter's age is 9 and the father's age is 35). The student formulated conclusions in accordance with the variables that have been provided. Students with interpersonal learning style tend to write answers with a lot of scribbles, but the results are correct and in accordance with the indicators of mathematical communication skills. Since the test questions were done individually, students with interpersonal learning style experienced difficulties as they learn better in groups. This is relevant to Ramlan's opinion (2014) that students with interpersonal learning style have difficulties in doing independent works since learning in the real world is lacking. 
Self-expressive Learning Style Subject
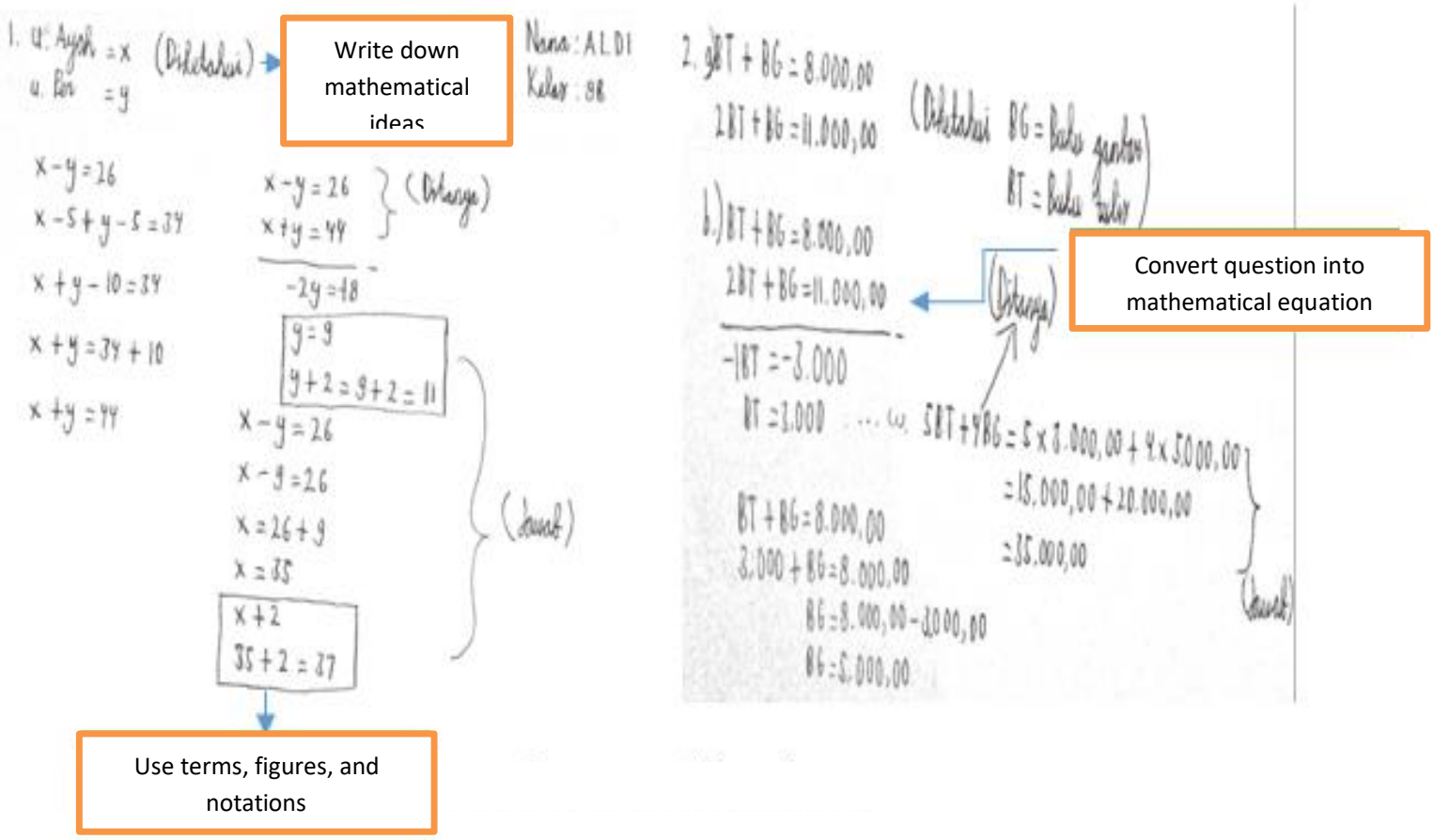

Figure 4: Student A's Answer

Student A with self-expressive learning style answered the questions by writing down the given and problem incorrectly. The student wrote down ayah (father) $=\mathrm{x}$ and anak perempuan (daughter) $=y$, which were supposed to be umur ayah (father's age) $=x$ and umur anak perempuan (daughter's age) $=\mathrm{y}$. Formulation used were correct, the student wrote down $\mathrm{x}+\mathrm{y}=44$ and $\mathrm{xy}=26$. All symbols used were correct, the student wrote down (+), (-), (=) symbols correctly. However, the student did not formulate any conclusions. Overall, the student wrote down the answers correctly. However, the answers were not systematic. The student used brackets instead of equals sign (=) to write down the given and problem. This proves that students with self-expressive learning style tend to take new, unusual ways, as long as the results can be obtained. As stated by Jean (2015), students with self-expressive learning style are able to express ideas in new ways and solve them in various ways.

\section{CONCLUSION}

Mathematical communication skills in mathematics learning were important to find out students's ability. The results of analysis on students' mathematical communication skills in completing SLETV material viewed from the learning styles of class VIII-B students at SMP Muhammadiyah 2 Malang showed that students with mastery learning style only wrote down the given and did not wrote down the problem in solving mathematical problems. They used incorrect formulation, correct symbols, correct conclusions, and correct results. In line with that, students with mastery learning style focused more on the results. They were able to solve questions about SLETV according to the four indicators of mathematical communication skills. Students with 
understanding learning style experienced difficulties in learning by discussing with peers. They learned better individually.

Students with interpersonal learning style were able to solve questions about SLETV, yet they did not wrote down the problem. They used correct formulation, correct symbols, correct conclusions that were in accordance with variables. Students with interpersonal learning style learned better in groups. Students with self-expressive learning style were able to wrote down the given, problem, formulation, and conclusions correctly. However, students with self-expressive learning style tended to solve a problem in many ways until they obtained the results.

\section{REFERENCES}

Afnaria. (2012). Kemampuan Komunikasi Matematis dan Pembelajaran Interaktif. Jurnal Pendidikan Matematika Vol.1 No. 1 Part $2: 77-8$

Auliana, Novi. (2017). Analisis Kemampuan Komunikasi Matematis Siswa Pada Materi Statistika Ditinjau Dari Gaya Belajar Visual, Auditorial, Kinestetik (Vak). Jurusan Pendidikan Matematika. FKIP. Universitas Nusantara Persatuan Republik Guru Indonesia.

Ferrara, Jean. (2015). The Effect Of Learning Style Strategies On Benchmark Eight Grade middle School Mathematics Achievment. Walden University

Gordah, E,K. Nurmaningsih. 2015. Analisis Kemampuan Komunikasi Matematis Mahasiswa pada Materi Kuliah Geometri Analitik di Program Studi Pendidikan Matematika IKIP PGRI Pontianak. Jurnal Pendidikan Informatika dan Sains, Vol. 4 (2)

Keliat, Ramlan. (2014). Perbandingan Gaya Belajar Interpersonal dengan Gaya Belajar Penguasaan Terhadap Hasil Belajar Matematika Mahasiswa Calon Guru. Jurnal Matematika Vol 2 No 1 Hal 221-226

Kosko, K. J,Wilkins. 2012. Mathematical Communication and Its Relation to the Frequency of Manipulative Use. International Electronic Journal of Mathematics Education, Vol.2, No.5, hal.1-12. Tersedia di http://www.mathedujournal.com/dosyalar/IJEM_v5n2_2.pdf [diakses 26 desember 2015]

Lestari, Karunia Eka dan Mokhammad Ridwan Yudhanegara. 2014. Penelitian Pendidikan Matematika. Bandung: PT Refika Aditama.

Mas'udah, A. Nur. (2016). Analisis Kemampuan Komunikasi Matematis Ditinjau Dari Gaya Belajar Pada Model Pembelajaran Knisley. Jurusan Pendidikan Matematika. FMIPA. Universitas Negri Semarang

Mulyono. 2012. Strategi Pembelajaran, (Malang: UIN-Maliki Press), hlm. 226-228

Silver, H. F.dkk. 2013. Pengajaran Matematika, Kurikulum Inti Bersama, Seri Pengajaran Tematik Integratif. Jakarta: PT. Indeks

Sukadi. 2008. Progressive learning: Learning by spirit. Bandung: MQS

Wardhana, I. R., \& Lutfianto, M. (2018). Analisis Kemampuan Komunikasi Matematis Ditinjau Dari Kemampuan Komunikasi Matematika Siswa, Surabaya, Jurnal Pendidikan Matematika (Vol. 6 Nomor 2 Tahun 2018). 
Zainul. (2016). Analisis Kemampuan Komunikasi Matematika Dalam Menyelesaikan Masalah Pada Pokok Bahasan Sistem Persamaan Linier Dua Variabel Siswa Kelas VIII-C SMP Nuris Jember. Jurusan Pendidikan Matematika. FMIPA. Universitas Negri Bandung. 